\title{
The College Physical Education Teaching Evaluation based on the Fuzzy AHP-Entropy and the Computer Simulation
}

\author{
Suhui Wang \\ Henan University of Technology, Zhengzhou, Henan, China \\ 5916668@qq.com
}

\begin{abstract}
At present, the higher education pays more attention to the improvement of the teaching quality, not the scale expansion. Constructing the scientifid reasonable evaluation index system of college physical education teaching is the basis ana prerequisite for the education administrative department to launch the appraisal work. The ropid development of the computer technology not only brings the convenience in the daily life, but also provides the new ideals and methods for the college physical education teaching evaluation. The combination between the college physical edwation teaching evaluation and the computer technology becomes the development trend in gurrent college physical education evaluation work. AHP method is an important assessment method However, in traditional AHP method, human subjectivity may cause a certain impact on the assessment results. In this paper, we propose the Fuzzy AHP-Entropy mefRod? This method can reduce the influence of the human subjectivity on the results. We apply this method to college physical education teaching evaluation. Then we use the computer simulation to obtain the evaluate results. Finally, the computer simulation experiment shows that the method is scientific, operability and efficient.
\end{abstract}

Keywords: Fuzzy AHR-Entropy, college physical evaluation, the computer simulation

\section{Introduction}

21 century is the computefera. Computer technology is in people's daily life. It brings a lot of conveniences for us. At the same time, the computer technology combines with some noncomputer field. And it takes the new change for the development of these fields. In recent years, the Ministry of Education puts forward to improving the quality of higher education. And Ministry of Education establishes the Higher Education Evaluation Center of the Ministry of Education. With the improvement of the concern about the health of young people, the eyaluation work of the college physical education becomes more and more important.

The study of the college physical education evaluation attracts many scholars. Li Guodong and Wang Kunlun thought Physical education curriculum is an important part of higher education, which plays an important role in the process of improving college student quality. And they studied the evaluation system of the ordinary college physical curriculum quality [1]. Tian Wenxue discussed the questions of the content, dimensions, standard, subject and process etc about the current college physical education quality from the literature review [2]. Zhang Sushi used the questionnaire survey method, the mathematical statistics and the logical analysis to study the practice of the college physical education assessment of the developed and the undeveloped areas. He analyzed the existing problems and proposed the related suggestions [3]. Shang Bao-zeng and Li Shi-sheng constructed the ordinary university sports education evaluation index system and established the comprehensive evaluation formula [4]. 
In the reality life, there are many evaluation methods. We often use AHP[5-6],ANP[7-8], DEA[9-10] and TOPSIS[11-12]. With the development of the times, many assessment methods begin to combine for producing the new assessment methods. The AHP method is as an example. Through the combination with other methods, AHP method develops many other methods, such as DEA-AHP [13-15], TOPSIS-AHP [16-17], Fuzzy-AHP and SWOT-AHP [19-20] etc. In the existing AHP, the human subjectivity will greatly affects the results. This makes the evaluation results can not reflect the actual situation. Based on this, we propose the Fuzzy AHP-Entropy. The method is based on the traditional AHP. According to modify the weight by using the entropy method and get the evaluation scores by using the fuzzy method. The structure of this paper is as follows. The first part is the introduction. In this part, ${ }^{\circ}$ we introduce the related work. The second part is the calculation steps of AHP-Entropy method. The third part is the improved AHP-Entropy method. In these parts, we firstly introduce the traditional AHP-Entropy, then, we propose the Fuzzy AHP-Entropy. The fourth part is the distribution of the weight. In this part, we express how to distribute the reights. The fifth part is the simulation experiment and the results analysis and the lastpart is the conclusion.

\section{The Calculation Steps of AHP-entropy Method}

(1)According to the scaling theory, we structure the compared matrix $A$ :

$A=\left(a_{i j}\right)_{n \times n} \quad(i=1,2, \cdots, n), a_{i j}=1, a_{i j}=1 / a_{A_{3}}$

(2)Normalizing the judgment matrix $\$$

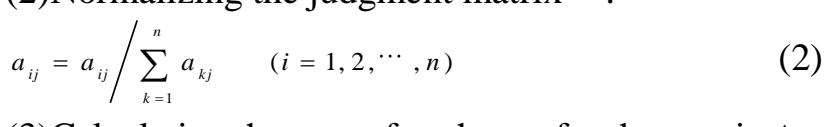

(3)Calculating the sum of each row for the matrix $A$ :
$\omega_{i}=\sum_{j=1}^{n} a_{i j}$
$(i=1,2$,

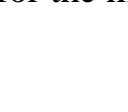

(4)Normalizing the sum of each ron about the matrix $A$ :

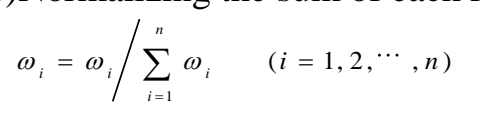

(5)According to $A \omega=\lambda$, we derive the maximum eigenvalue and its eigenvector.

(6)Check the consistehcy. If it goes through the consistency test, the feature vector will be as the weight of each index about the matrix.

(7)Calculating the entropy $e_{j}$ of the $j$ index:

$e_{j}=-k \sum_{i=1}^{m} p_{i j} \ln p_{i j}$

Among them, $k>0 e_{j}>0$. If $x_{i j}$ is equal to each other for the given $j$.

$P_{i j}=\sum_{i=1}^{x_{i j}} x_{i j}=\frac{1}{m}$. At the same time, $e_{j}$ has the maximum value:

$e_{j}=k \ln m \cdot k=\frac{1}{\ln m}, 0 \leq e_{j} \leq 1$.

(8)Use the alienation coefficient $g_{j}\left(g_{j}=1-e_{j}\right)$ of the entropy method to adjust the weight of AHP. Then we can get the comprehensive weight.

$$
w_{j}=w g_{j} / \sum_{j=1}^{n} w g_{j}
$$


(9)Getting the entropy coefficient matrix, we rank it comprehensively.

The process steps of the AHP-entropy method are as follows.

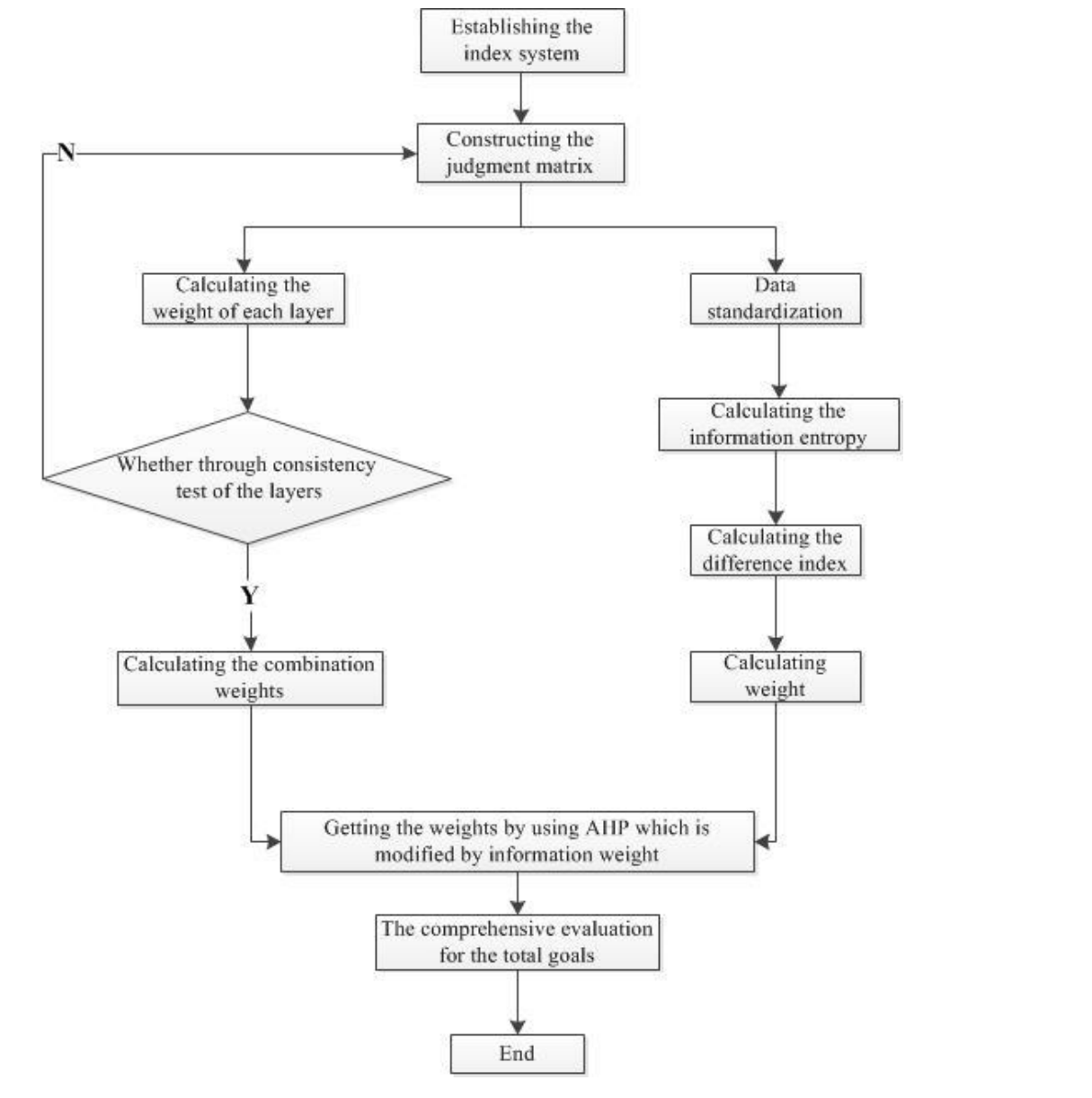

Figure 1. The Steps of the AHP-entropy

\section{The Fuzzy AHP-Entropy Method}

AHP-entropy method can only order the important degree for the targets. It cannot directly reflect the different degree about the sample. However, we need to evaluate the risk system of the electronic bank. We make the comment sets fuzzy processing and then we get the evalualed results of the evaluated scores. Firstly, we use the AHP method to get the weight of each index. Then we use the entropy method to adjust the weight and get the comprehensive weight. Lastly we combine the comprehensive weight with the comment sets and get the finial evaluated scores.

In this paper, we propose the Fuzzy AHP-Entropy. Firstly, we get the weight through AHP. Then we adjust the weight and get the comprehensive weight through the entropy value. At last, we make the comment sets fuzzy processing and then we get the evaluated results of the evaluated scores. The steps of the improved AHP-entropy are as follows.

(1)We establish the index system $L=\left\{L_{1}, L_{2}, \cdots, L_{i}\right\} ;(i=1,2, \cdots, n)$ and the comment sets $V=\left\{V_{1}, V_{2}, \cdots, V_{j}\right\} ;(j=1,2, \cdots, m) . L_{i}$ is the evaluation indicator. 
(2) We construct the two level index judgment matrix and we derive the maximum eigenvalue and its eigenvector according to $A \omega=\lambda_{\max } \omega$,

(3) Repeating the step (2), we calculate the weight of the different index.

(4) We calculate the entropy value $e_{j}$ of the $j$ indicator according to the formula (5).

(5) We adjust the entropy difference coefficient $g_{j}\left(g_{j}=1-e_{j}\right)$ to adjust the weight of the AHP according to the formula (6).

(6) According to the comment sets, we obtain the third index evaluation matrix $L=\left(L_{i j}\right)$ which is normalized. We multiply the evaluation matrix and the comprehensive weight of the third index. Then we get the evaluated results of the second index $\hat{C}=w^{\prime \prime} \cdot{ }^{\prime} L_{i j}$. We make the results as the input of the second indexes in order to make the first index evaluation result $N=w^{\prime \prime} \cdot B_{i j}$. At last, we get the index evaluation result $F=w^{\prime} \angle M \cdot w^{\prime \prime \prime}$ is the comprehensive weight of the third index. $w^{\prime \prime}$ is the comprehensive weight of the second index. $w^{\prime}$ is the comprehensive weight of the first index.

(7)We use $S=F \cdot V$ to get the final score of the e-commerce evaluation score.

\section{The Distribution of the Weight}

After establishing the college physical education evaluation we need to get the weights of the indicators. Firstly, we construct the judgment matrix of the index evaluation. Secondly, we calculate the maximum characteristic value and the feature vector of the judgment matrix. Thirdly, we check the consistencybased on the feature vector normalization, and then we take the feature vector as the index weight of the judgment matrix. After establishing the index weight, we use the entropy method to modify the weight and get the comprehensive weight.

We take the weighted calculation of the first index as a sample. The judgment matrix is shown as Table 1.

Table 1. The Judgment Matrix of the Criterion that is Relative to the Target
Layer

Firstly, we calculate the maximum eigenvalue and the corresponding feature vector of the second index layer which is relative to the first index layer $A$. We assume $\lambda_{\max }$ is the maximum feature vector. $W$ is the feature vector which $\lambda_{\max }$ corresponds. $\lambda_{\max }=4.0145$. The maximum eigenvalue and the maximum feature vector are as follows. 


$$
w_{i}^{(j)}=w_{i} / \sum_{i=1}^{n} w_{i}(j=1,2,3 ; i=1,2,3,4)
$$

We make the corresponding feature vector $W=\left(w_{1}, w_{2}, w_{3}, w_{4}\right)=(0.8278,0.4667,0.2694,01513)$ which is obtained from the maximum eigenvalue into the formula (3). Then we can get the new weight

$$
W^{(1)}=\left(w_{1}^{(1)}, w_{2}^{(1)}, w_{3}^{(1)}, w_{4}^{(1)}\right)=(0.8278,0.4667,0.2694,01513) .
$$

After we get the new weight, we check the consistency. $C I$ is the consistent test index. The order number of the judgment is $n$. The expression of $C I$ is as follows.

$$
C I=\frac{\lambda_{\max }-n}{n-1}
$$

The order number of the second index layer of the judgment matri $\hat{x}$ is fike. Therefore, $n=5$. We have known that $\lambda_{\max }=4.0145$ and $n=4$.

Then, we take $C I$ and $R I$ into the following formula.

$$
C I=\frac{\lambda_{\max }-n}{n-1}=\frac{4.0145-4}{4-1}=0.0048
$$
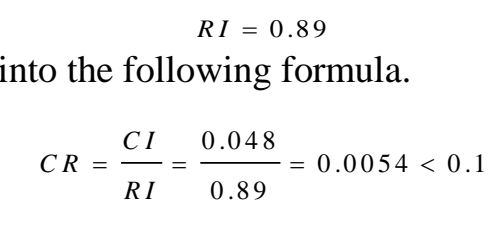

Due to $C R=0.0054<0.1$, the consistency testis right.

From the consistency tes? ye can know that the second index weights have passed the consistency test in the weightycalculation

Repeating the above method, we can obtain the weight of the second index layer about the electronic bank assessment system. Then, we modify the weights and get the comprehensive weights according to the formula (5) and (6).

\section{The Simulation Experiment and the Results Analysis}

At this part, we evaluate the college physical education teaching for one college. After collecting the data, we conduct the computer simulation. We get the weights of the first indexes firstly though the computer simulation. Then, we use the same method to get the weight of the second indexes and the third index. The results of the indexes are showed in the Table 2 .

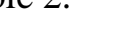

\section{Table 2. The Weights of the Different Indexes}

\begin{tabular}{|c|c|c|c|}
\hline The first index & The second index & The third index & weight \\
\hline \multirow{4}{*}{$\begin{array}{c}\text { The basic } \\
\text { resource } \\
\text { allocation }\end{array}$} & \multirow{4}{*}{ The teachers } & Ratio of teachers and students & 0.361 \\
\cline { 3 - 4 } & & Diploma and professional title structure & 0.394 \\
\cline { 3 - 4 } & & $\begin{array}{c}\text { Teaching } \\
\text { training }\end{array}$ & 0.082 \\
\cline { 3 - 4 } & \multirow{2}{*}{$\begin{array}{c}\text { The teaching } \\
\text { conditions }\end{array}$} & $\begin{array}{c}\text { The workload and the treatment for the } \\
\text { teachers }\end{array}$ & 0.173 \\
\cline { 3 - 4 } & & The sports funds & 0.252 \\
\hline
\end{tabular}




\begin{tabular}{|c|c|c|c|}
\hline & & The sports information & 0.404 \\
\hline \multirow{6}{*}{$\begin{array}{l}\text { The } \\
\text { curriculum } \\
\text { and the } \\
\text { teaching }\end{array}$} & \multirow{4}{*}{ The effect teaching } & The curriculum provision & 0.215 \\
\hline & & The curriculum design & 0.141 \\
\hline & & The teaching running and management & 0.312 \\
\hline & & The teaching monitoring & 0.342 \\
\hline & \multirow{2}{*}{$\begin{array}{l}\text { The curriculum } \\
\text { structure and the } \\
\text { teaching reform }\end{array}$} & The curriculum construction & 0.603 \\
\hline & & The teaching reform & 0.407 \\
\hline \multirow{7}{*}{$\begin{array}{l}\text { The } \\
\text { extracurricular } \\
\text { achievements }\end{array}$} & \multirow{4}{*}{ The group activities } & The organization and management & 0.226 \\
\hline & & $\begin{array}{l}\text { Morning exercises and the } \\
\text { extracurricular activities }\end{array}$ & \\
\hline & & The sunshine sports festiva & 0.262 \\
\hline & & The collective honor $\mathrm{A}$ & 0.331 \\
\hline & \multirow{3}{*}{$\begin{array}{l}\text { The training } \\
\text { competition }\end{array}$} & The sports training & 0.374 \\
\hline & & The sports competition performance & 0.343 \\
\hline & & The sports association competition & 0.293 \\
\hline \multirow{8}{*}{$\begin{array}{c}\text { The teaching } \\
\text { effect }\end{array}$} & \multirow{4}{*}{$\begin{array}{c}\text { The physical fitness } \\
\text { test }\end{array}$} & The test site and equipment & 0.148 \\
\hline & & Test regulations and monitoring files & 0.160 \\
\hline & & $\begin{array}{l}\text { The qualified rate of the physical } \\
\text { fitness for the students }\end{array}$ & 0.331 \\
\hline & & $\begin{array}{l}\text { excellent rate of the phy } \\
\text { Xfitness for the students }\end{array}$ & 0.371 \\
\hline & \multirow{4}{*}{ The daily teaching } & The lively lectures & 0.153 \\
\hline & & Movement skills & 0.322 \\
\hline & & $\begin{array}{l}\text { Mobilizing the enthusiasm of the } \\
\text { students }\end{array}$ & 0.180 \\
\hline & & Fostering the sports consciousness & 0.355 \\
\hline
\end{tabular}

After we get the weights of the different indexes, we calculate the entropy weight and the comprehensive weight of (the electronic bank assessment system according to the formula (5) and (6) through the computer simulation. The result is shown in Table 3.

Table 3. The Comparison Among the AHP Weight, the Adjusted Weight and the Comprehensive

\begin{tabular}{|c|c|c|c|}
\hline The third index & $\begin{array}{c}\text { The index } \\
\text { weight } w \text { of the } \\
\text { AHP method }\end{array}$ & $\begin{array}{c}\text { The index weight } \\
\bar{w} \text { of the entropy } \\
\text { method }\end{array}$ & $\begin{array}{c}\text { The } \\
\text { comprehensive } \\
\text { weight } w^{\prime \prime \prime}\end{array}$ \\
\hline $\begin{array}{c}\text { Ratio of teachers and } \\
\text { students }\end{array}$ & 0.361 & 0.358 & 0.359 \\
\hline $\begin{array}{c}\text { Diploma and professional } \\
\text { title structure }\end{array}$ & 0.394 & 0.396 & 0.396 \\
\hline $\begin{array}{c}\text { Teaching } \\
\text { training }\end{array}$ & 0.082 & 0.083 & 0.081 \\
\hline $\begin{array}{c}\text { The workload and the } \\
\text { treatment for the teachers }\end{array}$ & 0.173 & 0.163 & 0.164 \\
\hline The sports funds & 0.252 & 0.253 & 0.248 \\
\hline The sports facilities & 0.354 & 0.355 & 0.354 \\
\hline
\end{tabular}




\begin{tabular}{|c|c|c|c|}
\hline The sports information & 0.404 & 0.392 & 0.398 \\
\hline The curriculum provision & 0.215 & 0.213 & 0.212 \\
\hline The curriculum design & 0.141 & 0.139 & 0.140 \\
\hline $\begin{array}{c}\text { The teaching running and } \\
\text { management }\end{array}$ & 0.312 & 0.313 & 0.313 \\
\hline The teaching monitoring & 0.342 & 0.335 & 0.335 \\
\hline The curriculum construction & 0.603 & 0.605 & 0.595 \\
\hline The teaching reform & 0.397 & 0.395 & 0.405 \\
\hline $\begin{array}{c}\text { The organization and } \\
\text { management }\end{array}$ & 0.226 & 0.227 & 0.225 \\
\hline $\begin{array}{l}\text { Morning exercises and the } \\
\text { extracurricular activities }\end{array}$ & 0.191 & 0.192 & \\
\hline The sunshine sports festival & 0.262 & 0.261 & 0.259 \\
\hline The collective honor & 0.331 & 0.320 & 0.323 \\
\hline The sports training & 0.374 & 0276 & 0.377 \\
\hline $\begin{array}{c}\text { The sports competition } \\
\text { performance }\end{array}$ & 0.343 & & 0.347 \\
\hline $\begin{array}{l}\text { The sports association } \\
\text { competition }\end{array}$ & & & 0.276 \\
\hline The test site and equipment & & 0.146 & 0.147 \\
\hline $\begin{array}{l}\text { Test regulations and } \\
\text { monitoring files }\end{array}$ & & 0.157 & 0.158 \\
\hline $\begin{array}{c}\text { The qualified rate of th } \\
\text { physical fitness for the } \\
\text { students }\end{array}$ & & 0.329 & 0.329 \\
\hline $\begin{array}{l}\text { The excellent rate of the } \\
\text { physical fitness for the } \\
\text { students }\end{array}$ & & 0.368 & 0.366 \\
\hline The lively lectures & 0.153 & 0.155 & 0.148 \\
\hline Movement skills & 0.322 & 0.332 & 0.328 \\
\hline $\begin{array}{l}\text { Mobilizing the enthasiasm } \\
\text { of the students }\end{array}$ & 0.180 & 0.178 & 0.177 \\
\hline $\begin{array}{l}\text { Fostering the sports } \\
\text { consclousness }\end{array}$ & 0.355 & 0.335 & 0.347 \\
\hline
\end{tabular}

From the above steps, we get the comprehensive weight $w^{\prime \prime}$. We normalize the scores of the index. Because of space reasons, we only show the evaluation information of the first two third index layers for the college physical education teaching evaluation. The scores of evaluation information for the first two third index layers are as follows.

Table 4. The Index Scores of the College Physical Education Teaching Evaluation

\begin{tabular}{|c|c|c|c|c|c|}
\hline \multirow{2}{*}{$\begin{array}{c}\text { The first } \\
\text { index layer }\end{array}$} & \multirow{2}{*}{$\begin{array}{l}\text { The second } \\
\text { index layer }\end{array}$} & \multirow{2}{*}{$\begin{array}{c}\text { The third index } \\
\text { layer }\end{array}$} & \multirow{2}{*}{ Comment } & & \\
\hline & & & & grade & normalize \\
\hline \multirow{3}{*}{$\begin{array}{l}\text { The basic } \\
\text { resource } \\
\text { allocation }\end{array}$} & \multirow{3}{*}{ The teachers } & \multirow{3}{*}{$\begin{array}{c}\text { Ratio of } \\
\text { teachers and } \\
\text { students }\end{array}$} & excellent & 0 & 0 \\
\hline & & & fine & 5 & 1 \\
\hline & & & good & 0 & 0 \\
\hline
\end{tabular}




\begin{tabular}{|c|c|c|c|c|c|}
\hline & & & qualified & 0 & 0 \\
\hline & & & poor & 0 & 0 \\
\hline & & & excellent & 1 & 0.2 \\
\hline & & & fine & 4 & 0.8 \\
\hline & & professional & good & 0 & 0 \\
\hline & & title structure & qualified & 0 & 0 \\
\hline & & & poor & 0 & 0 \\
\hline & & & excellent & 0 & 0 \\
\hline & & & fine & 5 & 1) \\
\hline & & $\begin{array}{l}\text { training } \\
\text { tracning }\end{array}$ & good & 0 & 0 \\
\hline & & & qualified & 0 & 0 \\
\hline & & & poo & 0 & 0 \\
\hline & & & ine & $\frac{1}{3}$ & $\frac{0.2}{0.6}$ \\
\hline & & The & od & 1 & 0.2 \\
\hline & & & dalified & 0 & 0 \\
\hline & & & poor 2 & 0 & 0 \\
\hline & & & excellent & 0 & 0 \\
\hline & & & & 5 & 1 \\
\hline & & & good & 0 & 0 \\
\hline & teaching & & qualified & 0 & 0 \\
\hline & & & poor & 0 & 0 \\
\hline & & & excellent & 0 & 0 \\
\hline & & & fine & 4 & 0.8 \\
\hline & & & good & 1 & 0.2 \\
\hline & & & qualified & 0 & 0 \\
\hline & & & poor & 0 & 0 \\
\hline & & & excellent & 1 & 0.2 \\
\hline & & The curriculum & fine & 2 & 0.4 \\
\hline & & provision & good & 2 & 0.4 \\
\hline & & & qualified & 0 & 0 \\
\hline & & & poor & 0 & 0 \\
\hline & & & excellent & 0 & 0 \\
\hline curriculum & & The curriculum & fine & 5 & 1 \\
\hline $\begin{array}{l}\text { curriculum } \\
\text { and the }\end{array}$ & $\begin{array}{l}\text { The effect } \\
\text { teaching }\end{array}$ & design & good & 0 & 0 \\
\hline teaching & & & qualified & 0 & 0 \\
\hline & & & poor & 0 & 0 \\
\hline & & The teaching & excellent & 0 & 0 \\
\hline & & $\begin{array}{l}\text { running and } \\
\text { management }\end{array}$ & fine & 4 & 0.8 \\
\hline & & & good & 1 & 0.2 \\
\hline
\end{tabular}




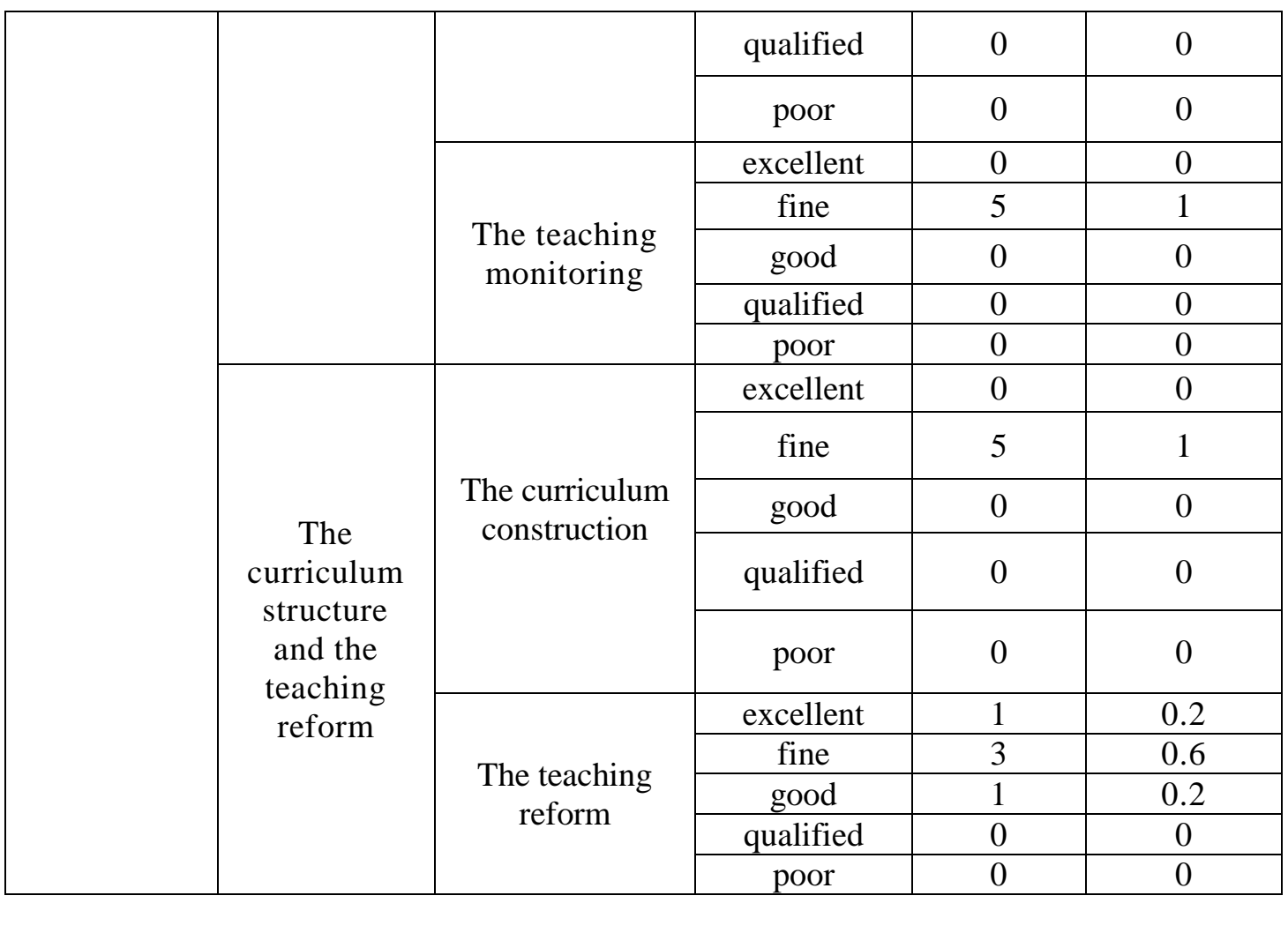

Then, we define the comment sets as follows?

$$
V=\left\{V_{1}, V_{2}, V_{3}, V_{4}, N_{3} \text { excellent, fine, good, pass, poor }\right\}==\{90,80,70,60,50\}
$$

We input the thirdhindex scores and the last evaluation index is as follows.

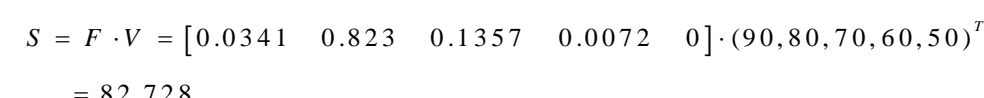

From the computer simulation, we can see that the experiment result is exact and exact. So, this method is scientific, operability and efficient. The Fuzzy AHP-Entropy method can be as amassessment method of strong adaptability.

\section{The Concilusion}

The rapd development of the computer technology not only leads to a lot of new industries. but also provides new vitality for the development of the traditional industries. In college physical education teaching evaluation work, we combine the evaluation work with the computer technology. It can not only get the accurate assessment results quickly, but also provide a new thought for other education evaluation work. The paper did the following works. (1)Firstly, we establish the university sports teaching evaluation system. (2)Secondly, we propose a new AHP method. This method is Fuzzy AHP entropy method. The method can reduce the influence of human subjective on the evaluation results. (3)Lastly, by using the computer simulation, we apply the method to the university sports teaching evaluation. The experimental results show that this method is scientific, operability and effective. 


\section{References}

[1] G. Li and K. Wang, "The Evaluation Index System Construction in Quality of Physical Education Curriculum in Universities", Modern Education Management, vol. 3, (2014), pp. 46-50.

[2] W.-X. Tian, "Analysis of the current situation of the evaluation of College PE teaching quality in China", Sport Science and Technology, vol. 6, (2013), pp. 107-110.

[3] S. Zhang, "Analysis of Practicality of Teaching Appraisal for Physical Education in Colleges [J]", Journal of Jixi University, vol. 9, (2012), pp. 149-151.

[4] B.-Z. Shang and S.-S. Li, "The establishment and evaluation of the ordinary university sports education evaluation index system", Journal of Sports Adult Education, vol. 26, no. 6, (2010), pp. 81-83.

[5] E. R. Jalao, T. Wu and D. Shunk, "A stochastic AHP decision making methodology for imprecise preferences [J]”, Information Sciences, vol. 207, no. 20, (2014), pp. 192-203.

[6] W. Pedrycz and M. Song, "A granulation of linguistic information in AHP decision-making problems", Information Fusion, vol. 17, (2014), pp. 93-101.

[7] S. Zaim, M. Sevkli, H. Camgöz-Akdağ, O. F. Demirel, A. Y. Yayla and D. Delen, "Use of ANP Weighted crisp and fuzzy QFD for product development", Expert Systems with Applications, vø1. 41, nø. 9, (2014), pp. 4464-4474.

[8] H. Y. Kim, K. W. Cho, D. G. Kang and H. S. Lee, "Oleanolje acid increases plasma ANP levels via an accentuation of cardiac ANP synthesis and secretion in rats, European Journal of Pharmacology, vol. 710, (2013), pp. 73-79.

[9] H. Fukuyama, Y. Maeda, K. Sekitani and J. Shi, "Input-output substitutability and strongly monotonic pnorm least distance DEA measures", European Journal of Operational Research, vol. 237, nos. 3, 16, (2014), pp. 997-1007.

[10] W.-K. Wang, W.-M. Lu, Q. L. Kweh and I-T Cheng, "Does intellectual capital matter? Assessing the performance of CPA firms based on additive efficiency deconposition DEA", Knowledge-Based Systems, vol. 65, (2014), pp. 38-49.

[11] Z.-X. Wang and Y.-Y. Wang, "Evaluation of the provinctal competitiveness of the Chinese high-tech industry using an improved TOPSIS methød”, Expert Systems with Applications, vol. 41, no. 6, (2014), pp. 2824-2831.

[12] T. Rashid, I. Beg and S. M. Husnine, "Robot selection by using generalized interval-valued fuzzy numbers with TOPSIS", Applied Soft Computing, vol. 21,(2014), pp. 462-468.

[13] P. Yu and J. H. Lee, "A hybrid approach using twø-level SOM and combined AHP rating and AHP/DEA-AR method for selecting optimal promising emerging technology", Expert Systems with Applications, vol. 40, no. 1, (2013), pp. 300-314.

[14] S. K. Lee, G. Mogi. Z. L1, K. S. Hui, S. K. Lee, K. N. Hui, S. Y. Park, Y. J. Ha and J. W. Kim, "Measuring the relative efficiency of hydrogen energy technologies for implementing the hydrogen economy: An integrated fuzzy AHP/DEA approach”, International Journal of Hydrogen Energy, vol. 36, no. 20, (2011), pp. 1265512663.

[15] A. Azadeh, S. F. Ghaderi and H. Izadbakhsh, "Integration of DEA and AHP with computer simulation for railway system improvement and optimization”, Applied Mathematics and Computation, vol. 195, no. 2, (2008), pp. 775-785.

[16] O. Taylan, A. O. Bafail, R. M.S. Abdulaal and M. R. Kabli, "Construction projects selection and risk assessment by fuzzy AHP and fuzzy TOPSIS methodologies”, Applied Soft Computing, vol. 17, (2014), pp. 105-116.

[17] S. K. Patil and R. Kant, "A fuzzy AHP-TOPSIS framework for ranking the solutions of Knowledge Management adoption in Supply Chain to overcome its barriers", Expert Systems with Applications, vol. 41, no. 2, (2014), pp. 679-693.

[18] R. Eslamipoor and A. Sepehriar, "Firm relocation as a potential solution for environment improvement using a SWOT-AHP hybrid method", Process Safety and Environmental Protection, vol. 92, no. 3, (2014), pp. 269276.

[19] R. Eslamipoor and A. Sepehriar, "Firm relocation as a potential solution for environment improvement using a SWOT-AHP hybrid method", Process Safety and Environmental Protection, vol. 92, no. 3, (2014), pp. 269276.

[20] A. Görener, K. Toker and K. Uluçay, "Application of Combined SWOT and AHP: A Case Study for a Manufacturing Firm”, Procedia - Social and Behavioral Sciences, vol. 58, no. 12, (2012), pp. 1525-1534. 


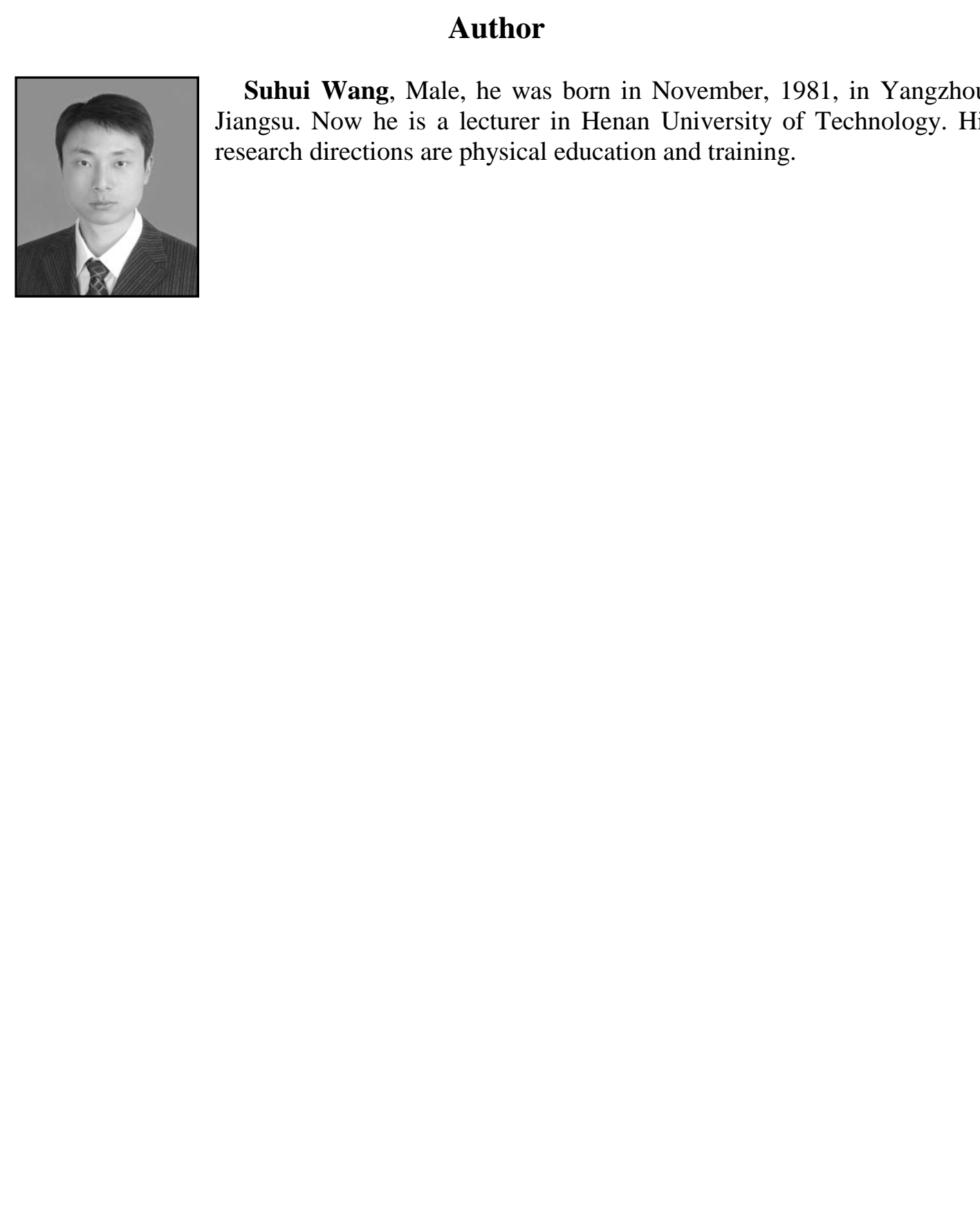


International Journal of Multimedia and Ubiquitous Engineering Vol. 9, No. 10 (2014)

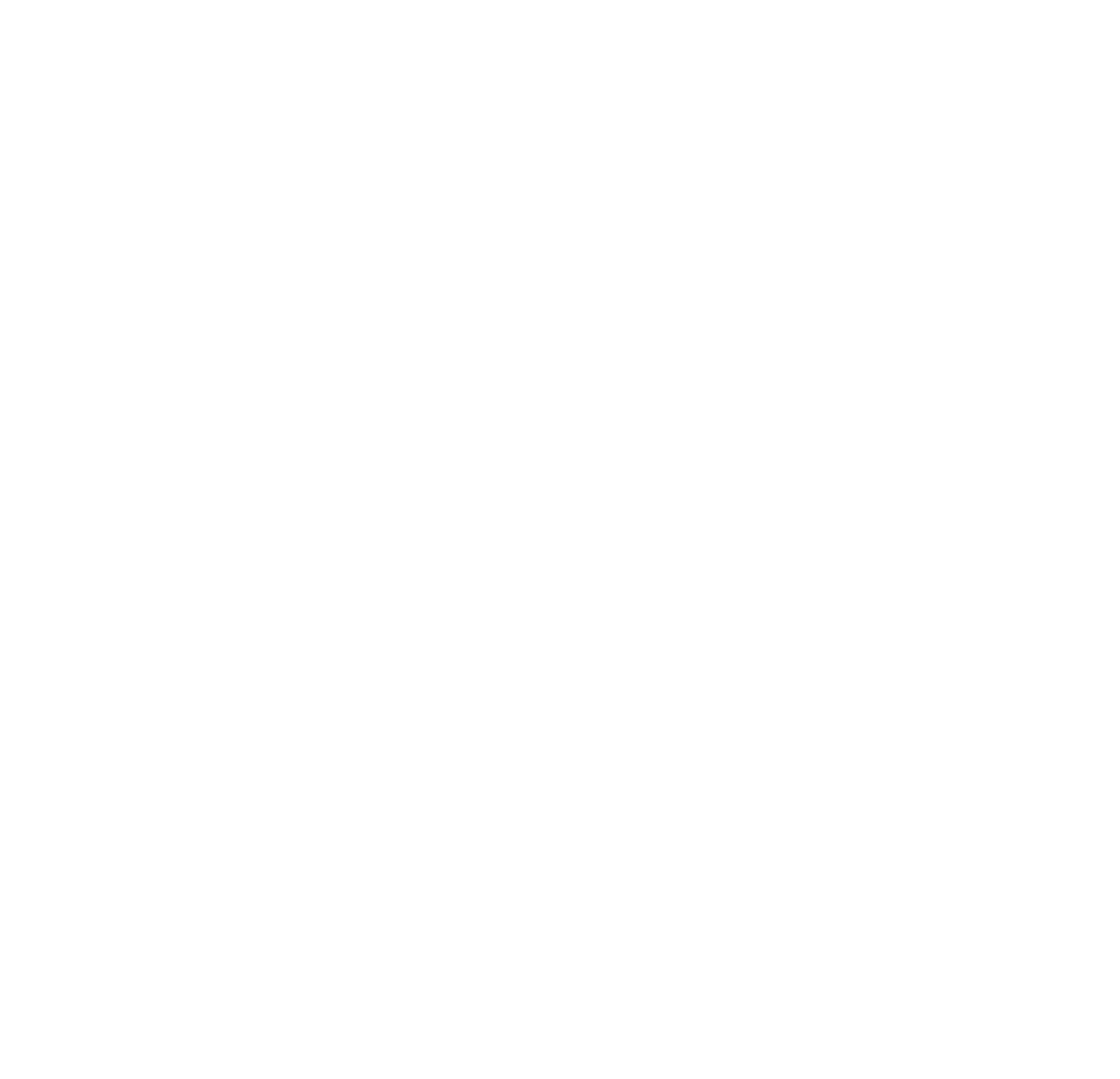

